\title{
Odious Debts and International Fair Trade
}

\author{
Deudas Odiosas y Comercio Internacional Justo
}

CRISTIAN DIMITRIU*

\begin{abstract}
I argue that one of the most important reasons why international trade has been unfair is that weaker parties in trading negotiations have been illegitimately forced to accept terms of trade that they would not otherwise accept under normal circumstances. Odious debts are at the center of this kind of injustice. Odious debts are sovereign debts that are not binding for the state, as public officials have used the money for private purposes. Creditor countries have taken advantage of the fact that countries are burdened with odious debts by tailoring trade agreements in their favor.

Keywords. Fair Trade, Odious Debts, Global Justice, Coercion, World Poverty
\end{abstract}

\begin{abstract}
Resumen: Sostengo que una de las más importantes razones por las cuales el comercio internacional ha sido injusto es que las partes más debiles en las negociaciones comerciales han sido ilegítimamente forzadas a aceptar términos de comercio que no hubieran aceptado bajo condiciones más normales. Las deudas odiosas están en el centro de este tipo de injusticia. Las deudas odiosas son deudas soberanas que no son vinculantes para un estado, ya que los oficiales públicos que la contrajeron usaron el dinero para fines privados. Los países acreedores han utilizado la desventaja creada por el peso de las deudas odiosas para conseguir condiciones de comercio más favorables.
\end{abstract}

Palabras Clave. Comercio Justo, Deudas Odiosas, Justicia Global, Coerción, Pobreza Mundial.

International trade has an enormous impact on the lives of people in both rich and poor nations. Trade is an activity that involves massive amounts of money globally - certainly more than aid and loans - and it is the main source of income for most poor countries ${ }^{1}$. The literature on global justice has tried to solve the puzzle of what constitutes fair trade. It has done so by developing an account of the principles of fairness under which international transactions should operate. By proposing these principles, this literature has certainly provided insight on how to reform currently existing practices. However, it has not been very specific about how the international trade regime is failing to live up to these principles of

Recibido: 15/11/2016. Aceptado: 28/10/2018.

* Investigador CONICET, Argentina. Profesor Adjunto Filosofía del Derecho, Universidad de Buenos Aires. Email cristiandimi@gmail.com. Área de especialización: Filosofía Política, Justicia Global, Filosofía del Derecho.

1 According to the World Trade Statistical Review 2017, world trade in 2016 involved around 20 trillion US Dollars. See report here, page 15.https://www.wto.org/english/res_e/statis_e/wts2017_e/WTO_Chapter_02_e.pdf. A big portion of that amount goes to developing countries. 
fairness ${ }^{21}$. In this article, I will fill this gap, and show a way in which global trade can be considered to be unfair. I will argue that one of the most important reasons why the international regime has been unfair is that poorer countries have been unfairly coerced to accept terms of trade that they would not have accepted under normal circumstances. The international regime, thus, has consistently failed to respect the requirement of 'voluntariness' that is central to any account of fair trade. How have weaker parties been coerced? Many poor states are saddled with odious debts; that is, with debts that are not binding, as they were incurred by corrupt rulers in the name of all the state, but used for purposes for which they were not authorized, such as their personal interest, or to oppress the population ${ }^{32}$. Despite the fact that these debts are not binding - that is, that there is no moral obligation to repay them-creditor countries have forced debtor countries to repay them and, more importantly for the purposes of this article, creditors have used the threat to enforce these debts to obtain asymmetric and convenient trade deals ${ }^{43}$. Take the case of Haiti. The country, one of the poorest in the region, has been saddled with odious debts for decades. The debts are odious because Duvalier, their former president, embezzled most of the borrowed funds. Despite the immorality of the loans, creditor countries have been trying to recover the funds from the country, including interest rates associated with them. Clearly, Haiti lacks necessary funds to afford such burden. Creditor countries thus confronted Haiti with two options: not repaying the debt, in which case all the negative consequences of defaulting on a debt would follow (normally loss of reputations, exclusion from future loans, diplomatic and political sanctions); or liberalize the economy (that is, that the country unilaterally opens up the economy). If the country decides to liberalize the economy, new loans will be provided, so that the old (odious) debt can be repaid. Cases like these have been extremely common among poorest countries. The resulting state of affairs is not simply a convenient one for creditor countries and an inconvenient one for debtor countries: it is also an unjust one. By describing this mechanism, I show a kind of ongoing injustice that has not been mentioned before in the global justice literature so far, and a clear example of how the proposed requirement of voluntariness for fair trade has been violated.

In the article, I proceed as follows. In Section I, I explain one of the central principles on which any conception of fair trade relies: the principle of voluntariness. A necessary condition (although not a sufficient one) for trade transactions to be fair is that parties voluntarily trade with each other. In the remaining sections of the article I show how international institutions have violated the voluntariness principle on an ongoing basis, by coercing the poorest states into unfavourable trade agreements. I do this in two steps. In Section II, I explain what a coercive proposal is, by relying on the familiar account of coercion provided

2 See for example James (2005), James (2012a), James (2012b), Risse (2007), Kurjanska, \& Risse (2008), Risse \& Wollner (2014), Risse (2012), Moellendorf (2005), Miller (2017), Stiglitz, Stiglitz, \& Charlton (2005), Christensen (2015) and Walton (2014).

3 The problem of odious debts has affected most of the developing countries, as most countries have been ruled by autocratic or corrupt rules, which have used the money for non authorized purposes. Empirical studies that back this claim are in the following report http://www.cadtm.org/Overview-of-debt-in-the-South; and in Ndikumana \& Boyce (2011).

4 This mechanism is clearly described in Hassoun (2012). Also, a good source for the direct ruling mechanism over developing countries by the WTO can be found in Cohen \& Sabel (2006). 
by Wertheimer. In Section III, I explain how international trade practices are coercive, in the sense of 'coercion' provided by Wertheimer. As I will show, odious debts are a central piece of this mechanism.

\section{Section I - Unjust Trade}

The early years of the 21 st century have witnessed an explosion of works in global justice. The central question has been whether the standards of distributive justice that apply at the domestic level should also apply at the global level. There are several possible responses to this question, but we can group them into two different camps. On the one hand, 'statists' or 'nationalists' 54 have defended the view that standards of distributive justice only exist within states, meaning that states have special duties to their citizens. On the other hand, 'cosmopolitans' ${ }^{65}$ have defended the view that, in addition to domestic principles of distributive justice, there are global moral standards that should be followed (which include global principles of justice, but also notions of fairness such as reciprocity, equity, and human rights).

The debate, as structured, does not seem to capture important questions of international distributive justice. More specifically, this debate does not provide a clear and useful approach to understanding the moral dimension of the activity that, ironically, most affects the prospects of the citizens of poor nations: trade. This seems natural, given the fact that theories of global distributive justice and a conception of fair trade deal with different questions. While the former attempt to develop an account of how goods should be distributed among individuals (in other words, 'who is entitled to what'), the latter attempts to develop an account of the moral principles that guide the exchange of goods, once the agents that participate in the transaction legitimately own the goods that they want to exchange (in other words, 'how goods should be exchanged').

Despite the fact that the debate on global justice has not centered on the notion of 'fair trade', there is now a set of articles and books that engage with this topic ${ }^{76}$. The conclusions they have arrived at are diverse and dissimilar, and I will not review them here. However, they all share the view that a necessary condition for a trade transaction to be fair is that the transaction is agreed to voluntarily by all parties. This implies that a transaction cannot be fair if one of the parties in the transaction coerces the other one to trade (since coerced transactions are never voluntary). So although the literature on fair trade has not reached a strong consensus about the necessary conditions that need to exist in order for a trade transaction to count as fair, there is agreement about the fact that coercing one of the parties in a trade transaction is a sufficient condition for trade transactions to be unfair. Importing coffee from Colombia cannot be fair if the US forces the Colombian government or its producers to sell the coffee, under any reasonable account of fair trade.

It thus becomes relevant to show how exactly, in current international trade, the minimal standard of voluntariness is being violated. Just as developing a theory of the concept of

5 See for example Nagel (2005), Miller (1999) and Blake (2001).

6 See for example, Pogge (2002), Tan (2012), Brock (2009) and Caney (2005).

7 See fn. 2 
'harm' would tell us the conditions under which harm takes place, but not the real life cases in which harm is actually taking place, the few theories of fair trade developed so far discuss the conditions under which a trade transaction in general would be fair, but remain silent about the aspects of actual transactions that fail to adjust to these standards. If we want to reform current international trading rules and institutions, we need to understand what those injustices are, and why they are morally problematic.

The key issue here is that the burden of (odious) debts unfairly imposes a restriction of the policy space to negotiate trade agreements for debtor nations. In order to show that this is true, we first need to know what a coercive proposal is. Once we settle this issue, we will be able to show that the current international regime is shaped in such a way that it clearly satisfies all the relevant conditions of the definition of coercion that I provide.

\section{Section II - What is a coercive proposal?}

What is a coercive proposal? There are of course many possible accounts of coercion, and there is not yet agreement about what exactly constitutes a coercive proposal ${ }^{87}$. However, Wertheimer's account ${ }^{98}$ seems to provide essential components of coercion. Following his account, we can confidently say that the main elements of a coercive proposal can be defined as follows.

Proposals are coercive, Wertheimer says, when they are threats and not offers. A threatens $\mathrm{B}$ by proposing to make B worse off relative to some baseline, while A makes an offer to B by proposing to make $\mathrm{B}$ better off relative to some baseline. In more specific terms, there is a threat involved when, if $B$ does not accept A's proposal, B will be worse off compared to the relevant baseline position; and there is an offer involved when, if $B$ does not accept the proposal, he will be no worse off than the relevant baseline. So, for example, if a man proposes giving money to a beggar in return for a task (say, for washing his car), there is an offer involved, because the beggar would not be worse off if he refuses the proposal. However, if the same man proposes to kill the beggar if he does not wash his car, there is a coercive proposal involved, because the beggar would be worse off if he refuses the offer.

Now, the condition of the coercee being 'worse off' if he refuses the proposal can be interpreted in two different ways. First, the coercee can be threatened to be rendered worse off with respect to the situation in which he was before the proposal was made to him (that is, with respect to the pre-proposal situation). Second, the coercee can be rendered worse off with respect to the situation in which he ought to be, if he refuses the offer (that is, with respect to the situation that he is entitled to).

The case of the beggar is an example of someone who is threatened to be made worse off compared to the situation he was in before the proposal was made to him. A different, possible, example provided by Nozick, of a case where an agent is made worse off relative to the situation in which he ought to be (or relative to a "moral baseline", as Wertheimer calls it) is the following:

8 See "Coercion" for a detailed description of possible meanings of coercion. http://plato.stanford.edu/entries/ coercion/

9 See Wertheimer (1987). 


\section{The drowning case ${ }^{109}$}

$\mathrm{A}$ is drowning, and $\mathrm{B}$ offers $\mathrm{A}$ an agreement according to which $\mathrm{B}$ will throw $\mathrm{A}$ a life preserver only if A serves B for four hours a day for the rest of his life. It seems that it is rational for the person who is drowning to accept the proposal. It is clear, however, that the proposal is not a just one, if we admit that there was a previous moral duty from A to save $\mathrm{B}$ 's life. With respect to that moral baseline (the duty to save B's life), A is coercing B.

Let us assume that B prefers not to drown. Relative to a non-moral baseline, A is making an offer. In fact, he is proposing something to improve the drowning person's situation. However, relative to a moral baseline, B is making a threat. There is a moral requirement according to which A should save B's life, and with respect to that moral baseline, the drowning person is worse off.

Another way to put it is that by failing to fulfil the duty to rescue $\mathrm{B}, \mathrm{A}$ is reducing the options of $\mathrm{B}^{1110}$, and therefore coercing him. Instead of saving B at no cost, A confronts B with two alternatives: drowning or paying, both of which are worse than the option $B$ is entitled to. In the drowning case, as stipulated, A is not blameworthy for B's situation. B is simply about to drown, and the details as to what caused this situation are not really relevant in this context. A is responsible, however, for confronting B with two options, both of which worsen his situation. In this case, B must rationally decide the most convenient choice among the set of options available to him. But even if he has the possibility of benefitting by choosing the best available option, he is still being coerced, as the set of options are reduced by $\mathrm{B}$ relative to the set of options he should have. We should also notice that the simple fact that someone's options are reduced is not sufficient to consider an agent coerced. Of course, a rainy day reduces someone's options. This does not mean however that the agent is coerced in any relevant sense. Coercion takes place when two agents interact, and one of them reduces the options of the other.

It should be emphasized that, following Wertheimer's definition, a proposal only counts as coercive when it is A (and not someone else) that threatens to reduce B's options. Suppose that a third agent, $C$, or simply unfortunate or unfair circumstances, render an agent worse off, and A subsequently takes advantage of this situation. In this case, there is possibly exploitation involved (that is, unfair advantage taking), but not coercion, strictly speaking, as the agent is not made worse off relative to any relevant baseline. So having one's options reduced is not a sufficient condition for a proposal to be coercive. It is the coercer who should reduce the coercee's options in order for a proposal to count as coercive.

To sum up, there are two different possible ways of coercing someone. The first one is by threatening to make him worse off with respect to the situation in which he was ("your life or your wallet'); and the second one is by threatening to make him worse off with respect to the situation to which he is entitled to. In the former case, someone is made worse off

10 Nozick (1969), 449.

11 We should notice here that 'reducing' the options of B is not necessarily wrongful. The state, for example, reduces the options of citizens by coercing them to pay taxes. Normally, there is a threat implicit in the requirement to pay taxes: 'the taxes or a penalty'. We do not normally think, however, that forcing citizens to pay taxes counts as wronging them. 
relative to a pre-proposal baseline; and in the latter case, someone is made worse off relative to a moral baseline. In the latter case, the coercee is clearly wronged.

\section{Section III - What are Odious Debts?}

So far, I have relied on the central elements of an account of coercion. In this next section, I will show that current international trade is coercive, in the sense that it satisfies the definition of 'coercion' given so far. In other words, I will show how current international trade falls short of realizing the 'voluntariness' ideal that it embraces. Although other possible forms of unfair trade have been discussed by scholars in the past ${ }^{1211}$, this specific version of unfairness in trade has not been explored so far ${ }^{1312}$. Odious debts, I argue, are at the centre of this kind of coercion.

What are "odious debts"? Suppose that a corrupt public official from a country borrows billions of dollars from the international community in the name of the state he represents, and then uses those funds to buy luxury palaces for his daughter. Lenders are aware of this situation, but keep lending anyway, as they know that future governments will repay the debt. According to an old legal doctrine ${ }^{1413}$, these debts are odious. There is some disagreement among legal scholars about the exact definition of 'odious debts' ${ }^{1514}$. However, we can define a debt as odious (or non-morally binding) when they satisfy the following conditions: (i) borrowed funds are used for purposes for which the public officials are clearly not authorized (typically embezzlement, widespread human rights violations, nationalization of private debts) (ii) lenders' loan was not innocent: they knew, or should have known, that they were lending for purposes for which the public official was not authorized. Their loan, in other words, was not made in good faith ${ }^{1615}$.

The conditions under which citizens of states are not bound by public officials (or, conversely, the conditions under which public officials are not authorized to borrow in the name of the state) can be made clearer by relying on social contract theories. As these theories have shown, citizens are bound by states so long as they have good moral reasons to obey them. These moral reasons are, in part, that citizens voluntarily accepted or would be

12 Scholars have mentioned, for example, that the way trade is structured encourages a "race to the bottom" in trade and environmental standards, restrictive intellectual property rights, unfair subsidies and others. See for example Ronzoni (2009).

13 Some global justice scholars have a somewhat easy tendency to claim that international trade, as currently structured, is essentially coercive, because it is organized in a way that mainly benefits wealthy nations. (See for example Cohen (2010). Although I do not deny that the current trade regime benefits the wealthy more than the poor; I believe that such conception of international trade either relies on a wrong notion of coercion (in part because it confuses 'exploitation' with 'coercion'), or makes a claim that is so general (i.e. "all international trade is coercive"), that it fails to distinguish specific ways of coercion.

14 The term "odious debt" was used for the first time by the Russian legal scholar Nahum Sack. See Sack (1927).

15 See for example Khalfan, King, \& Thomas (2003). However, other definitions have been proposed. Jayachandran, Kremer and Shafter (2006), for example, hold that Odious Debts are "debts incurred by the government of a nation without either popular consent or a legitimate public purpose"; and King states that a debt is odious when funds are used "with an aim and for a purpose not in conformity with international law" (see King (2007), 18).

16 These conditions under which debts are odious have been developed in detail in Dimitriu (2015) and in Dimitriu (2017). 
able to accept being ruled by their governments. This act of authorization, however, is not unrestricted: it exists so long as governments act within their legitimate mandate; that is, so long as governments interpret citizens' rights in a credible way. There is a widely shared agreement between different theories of justice around the fact that there is a threshold below which any political action could not possibly count as a credible interpretation of the citizens' rights ${ }^{1716}$. Actions that would fall below this threshold would include embezzling public funds for personal enrichment, oppressing the population to remain in power, or to benefit friends and allies; restricting citizens' liberties; undermining their security; and using public funds to benefit private companies. Whenever public officials spend money from debts for any of these purposes, they overstep their legitimate authority as agents. Thus, they fail to legitimately represent the state and, consequently, its citizens are not bound by the state anymore.

What makes debts odious (or non-binding) then, is not that they are too onerous, or hard to pay. What makes them odious is also not (as Pogge and others have suggested ${ }^{1817}$ ), that they create wrong incentives for autocratic leaders who contribute to poverty. Often debts are a setback for peoples' economy, and we do not consider them immoral for that reason. What makes them odious, rather, is that the population of a state ends up burdened with a debt that it is not morally binding for them, as it was incurred by rulers for purposes for which they were not authorized. Although there is disagreement about what exactly does bind citizens, some political actions clearly and obviously do not bind citizens, as they do not count as a credible interpretation of their rights ${ }^{1918}$.

Despite the fact that the case for odious debts is strong, these debts are not recognized as odious by international law, and are consistently enforced on successor regimes. Successor governments that refuse to repay these debts usually face legal sanctions, embargoes, loose reputation and face the possibility of exclusion from international financial markets. Thus, citizens and future generations end up bearing the burden of debts to which they have never consented.

One might be initially tempted to believe that the injustice of odious debts is a small and isolated problem that only affects countries ruled by autocratic rulers who steal money. However, once we understand the conditions under which citizens are bound by governments, we will see that the injustice is much more pervasive than we might initially think ${ }^{2019}$.

It follows from the two conditions of odious debts stated earlier that, contrary to a possible misconception, the problem of odious debts affects not only countries ruled by autocratic rulers, but also countries governed by democratically elected leaders. This is because both kinds of governments can, in principle, fail to act in accordance with the minimal threshold of legitimate political actions that I have stipulated earlier. A dictator can of course embezzle money, oppress the population and benefit friends and allies; but leaders of a democratic government can do the same. The popular perception that the problem of odious debts is very narrow in scope is also proven wrong by the fact that, as defined, odious debts not

17 Such theories have been developed for example by Parrish (2009) and Stilz (2011).

18 Pogge (2001); Cohen (2010).

19 These conditions have been clearly explained and developed in Dimitriu (2015) and in Dimitriu (2017).

20 A secondary implication of making these conditions explicit is that the odious debt doctrine, or at least some versions and interpretations of them, will have to be modified and clarified. 
only include cases of embezzlement. They also include any kind of action in which public officials overstep their authority.

Despite the fact that it is hard to determine the exact amount of debts that should be classified as odious, we can see some figures that would give us an idea of the magnitude of the problem. We know, for example, that Africa currently owes around 140 billion dollars to the international community ${ }^{2120}$ Given the history of corruption and oppression of leaders of this region, and that international lenders knew about possible corrupt uses of the funds (the fact that these governments were corrupt or illegitimate was widely known), we can confidently state that a big portion of these debts is odious. Something similar could be said about Latin America. The region owes around 500 billion dollars to the international community, and many of these debts were contracted by dictators during the 70 s, so that they could remain in power, to benefit friends, or to suppress political opposition. We should also mention that if a debt is odious, interest rates associated with these debts will also be odious. This makes the problem even bigger.

So far, I have defined odious debts, and have argued that the problem is pervasive. In the next section I will show how odious debts connect with trade and, more specifically, how odious debts are at the centre of the problem of unjust trade.

\section{Section III - Odious Debts as a sufficient condition for unfairness in trade}

How do odious debts make international trade coercive and, thus, unfair? In other words, why are odious debts a sufficient condition for unfairness in trade? The way in which odious debts are at the centre of unfair trade is more or less simple and it has been common in the international arena in the past 50 years or so. This mechanism usually involves international lending agencies, such as the IMF and the World Bank (which are directly governed by rich creditor countries, normally in the G7 group), and debtor countries. I will analyze this mechanism in stages.

(1) First, developing countries inherit an (odious) debt from previous governments. Funds to afford the interest rates of this debt-not to mention the debt itself-are usually scarce. The reason why these funds are scarce is not only explained by the fact that the country is generally destitute, but also by the fact that the previous governments had been paying the usually high interest rates associated with the original debts. As I have shown earlier, the set of odious debts is presumably very big, so it is safe to say that developing countries have been saddled with billions of dollars in debts that they should not repay.

(2) Second, indebted countries incur in even more debt in order to repay the inherited debt. Not doing so would create the risk of the country having to default on the debt. Since defaulting is penalized by the international community through several different mechanisms - such as commercial sanctions, exclusion from future loans, legal actions against national assets based in creditor countries or loss of reputation-and countries' situations worsen even more after these sanctions are enforced ${ }^{2222}$, asking for more loans to repay the

21 See Ndikumana \& Boyce (2011).

22 A devaluation usually follows after a default, as has happened in Ecuador, Russia, Indonesia, and Argentina when they each declared a default, or as it will very probably happen if Greece declares a default on its debt, 
inherited debt becomes the lesser evil. Normally, these new loans are provided by the same agents who had lent money for odious purposes in the first place, and who are now enforcing them. In other words, the enforcers of odious debts and the agencies that provide new loans are, most of the time, one and the same: usually, the IMF and the World Bank. These institutions have been lending money to virtually any country, regardless of the nature of its regime, and put into effect these debts ${ }^{2323}$. Although there are 187 member countries of the IMF, policies are mainly dictated by those who fund it, which are basically the wealthier countries $^{2424}$. One might say here that the IMF and World Bank were the main lenders 30 or 40 years ago, but not anymore. In fact, during the 70's and 80's, the objection would go, these financial institutions were the main source of credit, but there was a shift to bonds in the 90's, and it is not clear who exactly the creditors are anymore. However, and despite the fact that international lending is now decentralized, the argument I am putting forward still stands. Once the loans are made, the state to which private lenders belong normally assumes the role of enforcer, and exerts pressure on the debtor countries to recover these debts. So the loans made by Italian pensioners to Argentina in practice counts as a loan made by the Italian state to Argentina, in the sense that the Italian state ends up being the actual enforcer, in the name of the pensioners, of the debts ${ }^{2525}$. Usually, creditor states are the same that rule the international financial institutions, namely the IMF and the World Bank.

(3) Third, international financial institutions demand that debtor countries unilaterally liberalize their markets in return for these news loans (which, as I said, are necessary to repay the old (odious) debt) ${ }^{2626}$. By 'unilateral trade liberalization' I basically mean that

after returning to the dracma. Devaluation is a decrease in the value of a country's currency relative to that of foreign countries. Devaluation, at least when it is not planned and is out of control of the country, almost automatically generates inflation and a loss of purchasing power of wages. The reason why a default normally entails devaluation is that hard foreign currency becomes scarce after a default, and therefore countries cannot maintain the pre-devaluation level of expenditure. Devaluation on the other hand generates revenues by boosting exports.

23 Also, these agencies determine the behaviour of private investors by recommending for them to lend or not to lend, and by offering a backup for debtor countries which reduces their vulnerability and consequently the risk that private investors face by lending. This fact reinforces the idea that the IMF is the main enforcer of the debt.

24 Currently voting power of members is proportional to the funds each of the member states contribute to the organization. Given that richer countries contribute more than poor ones, they have more voting power. The main contributor to the IMF is United States. The United States has always been the only country able to block a supermajority on its own. The 27 member states of the European Union have a combined vote of 32.07 percent.

25 There is another possible example, which clearly illustrates the point I am trying to make. Some of the private lenders on which Argentina defaulted its debt (the "holdouts") are located in the US, and the case is currently being considered in US courts. Because of the fact that the US courts, and international law in general, usually supports the claims of the private lenders, Argentine national assets in foreign countries are constantly under the threat of being embargoed.

26 The demand that debtor countries unilaterally liberalize trade has usually been made by asking states to implement SAPs (Structural Adjustment Programs). Given the importance of SAPs, we should discuss them in more specific terms. The literature on SAPs is too vast to summarize here. But some central features are worth mentioning. SAPs are created with the goal of reducing fiscal imbalances by promoting economic growth. It is assumed by those who design SAPs that the best way to promote growth is by implementing free trade reforms which, in more specific terms, mean trade liberalization, devaluation, financial liberalization, and privatization. "Trade liberalization" here means the elimination of obstacles to import or export to or from any country or, 
debtor countries are required to open up their domestic economy to foreign products, while creditor countries are not required to reciprocate ${ }^{2727}$. These demands are called, by the institutions themselves (such as the IMF), conditionalities, and they usually include other demands as well (for example, the requirement that debtor countries privatize public assets) ${ }^{2828}$. Given the fact that debtor countries obtain some benefit from unilaterally liberalizing the economy, namely that they obtain new loans in return for these conditions, and that they therefore avoid defaulting on their debts, they end up accepting these conditions. The trade agreement that they accept, however, is clearly worse than the agreement they would have otherwise obtained, in the absence of the need to incur in new loans. This is because a country that is not burdened with debts has more bargaining power, and is always free to opt out if it does not find the deal convenient. An alternative way in which creditor countries obtain good trade deals through international institutions is by implementing what has been called HIPC initiative, which basically reduces or condones the debts of poorest countries the condition being that these countries implement, among other things, trade liberalization policies. Noteworthy is the case of Congo, which recently negotiated a debt relief for $\$ 12.3$ billion dollars in return for economic reforms, despite the fact that, as mentioned earlier, most of its debts are almost certainly odious. So the injustice here is clear: debtor countries are forced to accept bad agreements, as a consequence of the fact that they are burdened with (odious) debts.

One might argue here that the problem I am now discussing is a small one, which does not really affect a vast number of countries. However, we should notice that the IMF/World Bank apply conditionalities on loans on an ongoing basis, and many of the debtor countries on which these conditionalities are demanded are affected by odious debts.

Now, it is not clear whether developing countries generally benefit from implementing conditions required in return for loans-empirical evidence about the matter does not seem to be conclusive. ${ }^{2929}$ But having such evidence, however, does not seem relevant to the point I want to make. Even if implementing conditionalities was successful at promoting economic growth, it is clear that trade would be worse for debtor countries than the trade arrangement that would exist in the absence of such conditionalities ${ }^{3030}$. In other words, if unilateral trade

in practical terms, that indebted countries are "encouraged" to remove their trade barriers, so that developed countries do not have obstacles to export their locally produced goods or to invest in developing countries. Trade liberalization, however, does not imply that the indebted country's counterpart (usually a developed country) also eliminates obstacles for importing or exporting goods; this only happens if the counterpart country considers it convenient.

27 One might argue here that any member country can lodge a complaint about any other trade barrier. However, as Stiglitz and others have shown, international trading mechanisms are unfair because in trade disputes, both de iure and de facto, developed countries are in a better position to prevail; and even if the less developed countries prevail, the enforcement mechanism is asymmetric. See Stiglitz and Charlton (2006).

28 The following paper, published by the IMF, shows the connection between conditionalities and trade liberalization. http://www.imf.org/external/np/pdr/cond/2001/eng/trade/

29 Stiglitz, for example, claims that trade liberalization demands make countries worse off most of the time, while Bhagwati claims that the opposite is true. See Stiglitz and Charlton (2006) and Bhagwati (2004).

30 It is not hard to prove that trading rules in general are asymmetric. Stiglitz, for example, shows that there has been very little progress in the reduction of trade protection and subsidies of farm-related products by developed countries - precisely the kind of products in which developing countries have a competitive advantage - and in 
liberalization conditionalities did not exist, developing countries would obviously be able to obtain better trade deals with their counterparts. This is because both trading partners would have to make concessions to each other in order to pursue their trading goals. When unilateral trade liberalization is enforced, however, these kinds of concessions have already been made by one of the parties and, consequently, its counterpart will not need to reciprocate in order to pursue its own economic goals. So if, for example, Ecuador wants to export bananas to the US, and the US wants to export manufactured products to Ecuador, they would both have to agree on a trading arrangement that would let the other export their own products. This could have negative consequences for banana producers in the US (assuming there are some) and for the local manufacturing in Ecuador, but overall, we can infer that both parties would benefit (assuming that there are no other issues involved, such as bribery, lack of knowledge and information, etc.). However, if Ecuador has already made these kinds of concessions and is already willing to import manufactured products from the US, (the US would not agree to allow bananas to be imported, and) the kind of deal Ecuador would obtain would obviously be worse than the one it would obtain when mutual concessions are made, even if it is still convenient. Selling bananas and importing manufactured products is obviously better than simply importing manufactured products.

So it might be true that it is convenient and rational for a country to accept conditions required by creditor countries in return for new loans. However, in certain contexts, doing something that could be a rational response to your situation is not justified, if you are compelled to do it because you are being placed at a disadvantage in advance. It becomes a poor option but also, just as significantly, the rational response to an illegitimate situation. The problem with the agreement, in other words, is not the pre-existing bargaining inequality between trading partners, for this inequality is not necessarily immoral and does not necessarily lead to an unfair outcome; but rather that one of the parties wrongly reduces the options of the other by exposing her to two different options, both of which make her worse, relative to the relevant baseline.

We can conclude from (1), (2) and (3) above that poor (debtor) countries suffer a double injustice. First, they are saddled with debts that they should not repay. Second, they are forced to trade with creditor countries under terms that are worse than the terms they would

non-agricultural goods in which developing countries also specialize. Stiglitz shows that developing countries face average manufacturing tariffs of 3.4 per cent on their exports to developed countries, more than four times as high as the average rate faced by goods from developed countries, 0.8 per cent. The picture might not be so clear for some. One might argue, for example, that the type of trade liberalization imposed on developing countries also favours their chance of exporting their domestically produced goods, as one of the conditions for SAPs was currency devaluation. However - with the exception of a few products of some specific countries the exports of the products in which developing countries have a comparative advantage have not in general increased after trade liberalization policies were implemented. Again according to Stiglitz, in the latest rounds of trade there was a focus on the liberalization of service industries, which are of primary interest to developed countries, and significantly less attention given to low-skilled, labour-intensive services in which developing countries have a comparative advantage. In Stiglitz's words, "developing countries have increased their export of services more than fourfold since 1990, despite the large trade barriers facing many of their most promising industries." The bottom line seems to be that the only sectors of the economy in which developing countries obtained a real advantage are precisely the sectors in which they had a small comparative advantage, while the sectors in which they have a real comparative advantage still face difficulties because of the protections and subsidies of developed countries. See Stiglitz Ibid. 
normally accept. Odious debts are at the basis of coercive trade agreements, as they are used as means to tailor trade agreements in favor of creditor countries.

\section{Odious Debts as coercive proposals}

How do odious debts and international trade satisfy the definition of 'coercion' mentioned earlier? I have stated that coercion is a threat that would, if complied with, make the agent worse off. So what is the threat that is making them worse off?

As I have shown, creditor countries confront debtor ones with two options, both of which make debtor countries worse off, relative to the situation in which they would be if the threat did not exist. The threat, basically, is that if debtor countries do not accept a (bad) trade deal (i.e. a trade deal in which they unilaterally liberalize their economy), new loans will not be provided, and consequently debtor countries will be pushed to default on their already existing debts, some of which are odious. Another way to put it is that creditor countries give debtor ones two options: they either accept a (bad) trade deal, or else (odious) debts are enforced on them. We should notice here that if the burden of odious debts did not exist, the result of the trade negotiations would obviously be different, because the bargaining power of the poorest countries would be stronger. We should also mention that if the debts were not odious (that is, if they were ordinary debts) the proposal of a (bad) trade deal would not really count as coercive, as the debtor country will not really be pushed to a situation which is worse than the situation in which it ought to be. The negotiation, in that case, would look like a normal negotiation to refinance an old debt. I will come back to this point later in the article.

One of the implications of the process I have described (i.e. 1, 2 and 3 above) is that one of the necessary requirements for trade to be fair is violated on an ongoing basis: the requirement that transactions between parties be voluntary. A theory of fair trade fails to identify this kind of unfairness, for the simple reason that it is too focused on elaborating the principles of fairness under which international trade should operate, and thus remains silent about the conditions that make trade unfair.

We should notice at this point that the argument I am putting forward has some obvious limitations. Clearly, not all proposals made by creditor countries are coercive; and not all debts in the world are odious. The argument applies under some conditions only. It is clear, however, that a substantial portion of trade agreements are made unfair by the burden of debts that should not even exist in the first place. In fact, odious debts, as shown earlier, are a pervasive problem, and unfair conditions attached to loans have been occurring on an ongoing basis.

\section{Possible objections}

There are a few possible objections one might raise against the account of unfairness in trade I have developed so far, and it is important to consider them.

First, someone might plausibly claim that there is no need to mention odious debts specifically to show that there is unfairness in trade, as any other unfair background conditions can also be used to make the exact same point. Could we not also mention, someone might 
ask, that colonialism, or general unfair international rules, or simply poverty, are also at the basis of unfair trading rules? Why single out odious debts? ? $^{3131}$

This objection, however, relies on a wrong interpretation of coercion. As explained earlier, when an agent, A, takes advantage of a harm inflicted by someone else, or takes advantage of unfair background conditions, that agent is exploiting $\mathrm{B}$, rather than coercing him. The difference is not a small one. In a typical case of exploitation, the exploited agent is not made worse off, and might even benefit from the transaction. In a case of coercion, someone is made worse off by the agent that coerces (if the agent complies with the demand) ${ }^{3232}$. The difference is not minor. A case where countries engage into asymmetric trade deals because they are burdened with normal debts, poverty, or any other misfortune, is at most a simple case of exploitation - that is, a case where a lender takes advantage of someone's vulnerabilities. In such scenario, rich countries obtain an unfair benefit, but do not really make poor ones worse off (the disadvantage had rather been created previously by some other agent or circumstance). In contrast, a case where countries engage into asymmetric trade deals with an agent, and this asymmetric deal is obtained through a threat of enforcing an odious debts, is a straightforward case of coercion. In this situation, debtor countries are made worse off, as they have to choose between facing the consequences of default for a debt that they do not really have, or entering intro trade agreements under very inconvenient terms. Consequently, in such scenario, the force of the claim against creditor countries is much stronger.

Second, one might argue that it is not really necessary to show that a debt is odious to make the case of unfair trade. Simply showing that debtor countries are burdened with debts, and that creditor countries take advantage of this burden by demanding convenient trade deals, would be enough to make the point. But this objection is also misleading. Demanding certain conditions in return for loans to someone who is already in debt does not count as coercion, but rather as a simple offer. Given that the agent is not made worse off under the terms of the proposal, the proposal cannot be considered coercive. For example, if a country inherits a debt that resulted from a loan made by another bank centuries ago, and this country borrows money from an agent that has absolutely no connection with the old bank, for the purposes of repaying the old debt, can we really say that the new agent is coercing the country when demanding conditions for loans? I do not think so.

Things look different, however, if the reason why clients need, or want to borrow money from international lenders has been unjustly created by lenders themselves, by generating a debt that is not binding in the first place. In those cases, conditions attached to loans are coercive, for the debtor's options are being unfairly reduced by the creditors themselves.

31 The point that general background conditions (in general) might be relevant for the assessment of the global order has been made for example by Ronzoni (2009).

32 The difference between coercion and exploitation, and how it affects our assessment of trade, has been clearly explained in Dimitriu (2014). The difference between the notions of coercion and exploitation have also been clearly discussed in Wertheimer (1999) and in Wertheimer (1987). For a lucid moral discussion of coercion see Nozick (1969). 


\section{Conclusion}

In this article I have not defended a conception of fair trade. Instead, I show a common way in which trade is currently unjust. Odious debts are at the center of the injustice in trade I want to point out.

The notion of 'voluntariness' lies at the center of any conception of fair trade. The requirement of voluntariness, however, is violated if creditor countries coerce countries into accepting terms of trade that they would not otherwise accept. The notion of coercion is a moral one, and assumes that a proposal is coercive when an agent is made worse off (whether she accepts or refuses the proposal), relative to a relevant baseline (e.g. moral or empirical). Creditor countries have coerced debtor countries into accepting trade deals under certain terms by enforcing non-binding (i.e. odious) debts on debtor countries. Debts are non-binding when borrowed funds are spent in accordance with non-autorized purposes. As a condition for new loans or funds to pay off these non-binding debts, creditor countries demand trade unilateralization (that is, open borders for their locally produced products). These kinds of proposals would not count as coercive if debts were not odious. Instead, they would count as offers, as they would not entail rendering an agent worse off relative to some baseline, but as making her better off relative to the pre-proposal situation. Debtor countries, in those scenarios, would face the dilemma of asking for certain conditions in return for new loans. This would be normal and acceptable, and the case of unfair coercion could hardly be made. The scenario would be analogous to one in which a domestic bank demands conditions in return for new loans.

\section{References}

Bhagwati, J. (2004). In defense of globalization: With a new afterword. Oxford University Press.

Blake, M. (2001). "Distributive Justice, State Coercion, and Autonomy". Philosophy and Public Affairs 30/3: 257-296.

Brock, G. (2009). Global Justice: A Cosmopolitan Account, Oxford: Oxford University Press.

Caney, S. (2005). Justice Beyond Borders: A Global Political Theory, Oxford: Oxford University Press.

Christensen, J. (2015). "Fair Trade, Formal Equality, and Preferential Treatment". Social Theory and Practice, 41(3), 505-526.

Cohen, J. (2010), "Philosophy, Social Science, Global Poverty". In: Jaggar A (ed.) Thomas Pogge and his Critics. Oxford: Polity Press.

Cohen, J., \& Sabel, C. (2006). "Extra rempublicam nulla justitia?.” Philosophy \& Public Affairs, 34(2), 147-175.

Dimitriu, C. (2014). "Free trade and exploitation". Daimon Revista Internacional de Filosofía, (62), 101-108.

Dimitriu, C. (2015). “Odious Debts: A Moral Account.” Jurisprudence, 6(3), 470-491.

Dimitriu, C. (2017). “Agency law and odious debts.” Ethics \& Global Politics, 10(1), 77-97. 
Hassoun, N. (2012) Globalization and Global Justice: Shrinking Distance, Expanding Obligations, Cambridge University Press.

James, A., (2005). "Distributive justice without sovereign rule: the case of trade". Social Theory and Practice, 31(4), 533-559.

James, A. (2012a), 'Global Economic Fairness: Internal Principles', in Carmody, C., Garcia, F. J., \& Linarelli, J. (Eds.). Global justice and international economic law: opportunities and prospects. Cambridge University Press.

James, A. (2012b). Fairness in practice: A social contract for a global economy. Oxford University Press.

Jayachandran, S., Kremer, M. \& Shafter. J. (2006), Applying the Odious Debt doctrine while preserving legitimate lending. Stanford Center for Democracy, Development and the Rule of Law. http://iisdb.stanford.edu/pubs/21472/ApplyingtheOdiousDebtsDoctrine.pdf;

Khalfan, A., King, J., \& Thomas, B. (2003). Advancing the odious debt doctrine. Center for International Sustainable Development Law. Working Paper COM/RES/ESJ, 11, available at http://www.dette2000.org/data/File/odious_debt_CISDL.pdf

King, J., The Doctrine of Odious Debt in International Law: A Restatement (January 21, 2007). Available at SSRN: http://ssrn.com/abstract=1027682 or http://dx.doi.org/10.2139/ ssrn.1027682)

Kurjanska, M., \& Risse, M. (2008). "Fairness in trade II: export subsidies and the Fair Trade movement". Politics, Philosophy \& Economics, 7(1), 29-56.

Miller, D. (1999). "Justice and Global Inequality", in A. Hurrell \& N. Woods (eds.), Inequality in World Politics, (Oxford: Oxford University Press).

Miller, D. (2017). "Fair trade: what does it mean and why does it matter?" Journal of Moral Philosophy, 14(3), 249-269.

Moellendorf, D. (2005). "The world trade organization and egalitarian justice". Metaphilosophy, 36(1 $\square 2)$, 145-162.

Nagel, T. (2005). “The Problem of Global Justice.” Philosophy \& Public Affairs, 33/2:11347

Ndikumana, L., \& Boyce, J. K. (2011). Africa's odious debts: how foreign loans and capital flight bled a continent. Zed Books.

Nozick, R. (1969) 'Coercion', in Morgenbesser, S, Suppes, P. and White, M. (eds.), Philosophy, Science and Method: essays in honour of Ernest Nagel, New York: St Martin's Press, 440-472.

Parrish, J. M. (2009). "Collective responsibility and the state." International Theory, 1(1), $119-154$.

Pogge, T. (2001). “Achieving democracy.” Ethics \& International Affairs, 15(1), 3-23.

Pogge, T. (2002). World Poverty and Human Rights. (Malden: Blackwell).

Risse, M. (2007). "Fairness in trade I: obligations from trading and the Pauper-Labor Argument". Politics, Philosophy \& Economics, 6(3), 355-377.

Risse, M. (2012). On global justice. Princeton University Press.

Risse, M., \& Wollner, G. (2014). "Three images of trade: On the place of trade in a theory of global justice". Moral Philosophy and Politics, 1(2), 201-225.

Ronzoni, M. (2009). “The global order: A case of background injustice? A practice $\square$ dependent account." Philosophy \& public affairs, 37(3), 229-256. 
Sack, A. N. (1927). Les effets des transformations des états sur leurs dettes publiques et autres obligations financièrs. Traité juridique et financier (Vol. 7). Recueil Sirey.

Stiglitz, J. and Charlton, A. (2006) Fair Trade for All: How Trade Can Promote Development. Oxford University Press.

Stiglitz, J. E., Stiglitz, S. F. J. E., \& Charlton, A. (2005). Fair trade for all: how trade can promote development. Oxford University Press.

Stilz, A. (2011). "Collective Responsibility and the State." Journal of Political Philosophy 19 (2): 190-208.

Tan, K. C. (2012). Justice, institutions, and luck: the site, ground, and scope of equality. Oxford University Press.

Walton, A. (2014). "Do Moral Duties Arise from Global Trade?" Moral Philosophy and Politics, 1(2), 249-268.

Wertheimer, A. (1987). Coercion, Princeton: Princeton University Press.

Wertheimer, A. (1999). Exploitation. Princeton University Press.

Wertheimer, A. (1987). Coercion, Princeton: Princeton University Press 